\title{
DEPORTES EXTREMOS. CONSTRUYENDO CAPACIDADES ESTATALES EN LA LUCHA CONTRA EL NARCOTRÁFICO: CASO ADUANA ARGENTINA 2005-2010
}

\author{
Jorge Augusto Depetris (*) \\ (Instituto de Estudios Tributarios, Aduaneros y \\ de los Recursos de la Seguridad Social -AFIP-)
}

\begin{abstract}
RESUMEN
El trabajo argumenta que la Aduana Argentina construyó capacidades para enfrentar el fenómeno del narcotráfico entre los años 2002 a 2008.Las preguntas que se intentan responder son: ¿fue efectiva la respuesta de la Aduana a la problemática del narcotráfico? ¿Qué capacidades desarrolló? ¿Cómo funcionan dichas capacidades?, y ¿porqué fueron efectivas? Para ello se efectúa una descripción de la problemática del narcotráfico en la región y la Argentina en particular, luego se efectúa una medición de impacto para probar que la Aduana con su accionar contribuyó a reducir el tráfico de exportación de cocaína a Europa. Se describen las transformaciones que se realizaron para enfrentar el desafío, y luego se analiza un caso concreto, donde dichas transformaciones interactuaron para lograr detener el tráfico de cocaína oculto en embarques de carbón. Se explica el éxito en la construcción de capacidades a una modalidad de gestión pública de tipo “artesanal”, en contraste con los tradicionales postulados de la mano dura y mano blanda.
\end{abstract}

PALABRAS CLAVE:

capacidades estatales, artesanía regulatoria, Aduana argentina, tráfico de drogas.

(•)E-mail: jdepetris@afip.gov.ar

\section{ABSTRACT}

It has been argued that Argentina Customs built capabilities to tackle drug trafficking from 2002 to 2008. The questions seek to answer are: Was effective the response from Customs?. What kinds of skills were developed? How do these skills work? Why were they effective? It built an impact measurement, to prove that Argentina's Customs was succesfull reducing cocaine traffic from Argentina to Europe. It is described the organizational changes that were made to cope with the problem, and then a description of a case where Customs stopped a big smuggling of cocaine hidden in shipments of coal. It shows how all of these organizational changes worked together to solve the problem. The case shows that successful capacity building is due to a "craftmanship" management approach, in contrast to the traditional of hard and soft hand.

\section{KEY WORDS:}

state capacities, crafts regulatory, Argentina Customs, drug trafficking.

RECEPCIÓN: 20/08/11

ACEPTACIÓN FINAL: 31/01/12 